\title{
Should I Stay Or Should I Go: The Role Of Communication In Striving To Retain Older Employees
}

Jana Žnidaršič, University of Ljubljana, Slovenia Sandra Penger, University of Ljubljana, Slovenia

Vlado Dimovski, University of Ljubljana, Slovenia

\begin{abstract}
The impact of population ageing that goes hand in hand with ageing of the workforce is already deeply felt on European labor markets - including Slovenian - and will manifest itself more prominently in the next years.
\end{abstract}

One of the most discussed policy options that would mitigate possible negative consequences of population and workforce ageing - is to promote that older employees work longer, even after the age of 65.

But this scenario is not an easy one. Prolonging working life can only be done by enabling older workers to remain productive, thus able and willing to work. By implementing active ageing policies at workplace, the employers can play an exceptional role in persuading older workers to prolong their working lives for their own well-being and for the good of society.

The aim of this paper is to highlight the importance of communication when older workers are deciding whether to stay or not.

Keywords: Ageing Workforce; HRM; Communication; Active Ageing; Age Management

\section{INTRODUCTION}

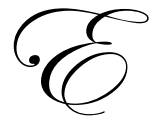

very day we can read a lot of literature that describes the aging population, how we will manage the healthcare of this growing group of individuals, how we will make our welfare states sustainable and how the growing numbers of older people will affect whole communities.

The demographic shift seems to be inevitable. Higher longevity and lower birthrate cause an aging population and workforce. Recently, the age structure of workforces in the industrialized world is changing profoundly. The population ageing drives an unprecedented shift in the age distribution of the general population and with it the labor pool. It might happen that there will not be enough younger and skilled workers to replace those who reach retirement age and we can expect skills and labor shortages. Consequently, companies in developed countries all around the world will need to hire more and more older people (workers), who would present the fastest growing source of additional labor. Simultaneously, employers must adjust their management practices to bring out the best in workers of all ages to minimize the problems and maximize the opportunities of demographic shift, by developing age management paradigm within companies.

Despite the fact, that the trend of employing older workers is widely spread in the most developed EU countries, in Slovenia, workers are still strongly inclined towards early retirement. Thus, the question of older workers' retention is very actual concern among HRM in Slovenian companies. 
The paper is focused on the role of communication when striving to convince older employees to prolong their working lives for their own well-being and for the good of society as a whole.

\section{WHY WOULD SOMEONE CONSIDER WHETHER TO PROLONG HIS (HER) WORKING LIFE OR NOT?}

At first sight, the question concerning »should I stay or should I go « seems to be crazy, since it can be assumed that retirement is a kind of reward and one would accept the first opportunity to exit from labor market, especially when this it economically affordable solution. It is true, that many older workers prolong their working life because of financial necessity. However, a closer look into the problem of decision making when coming on the crossroad shows us, that the decision about staying at work or not is always a very complex one.

Older workers, who remain in the workplace, rather than retiring, make their decisions based on several factors other than income alone. Beyond economic issues, social, mental and physical well-being plays a significant role in determining whether they will retire or remain in the workplace. However, the decision not to retire is also made for other reasons, such as the fear that the joys and benefits of retirement do not outweigh the losses they may experience (Roper, 2002). »For a number of older workers, coming to work is their central life-defining and lifesupporting activity. This is where their friends are, where they receive love, respect and caring" (from Voices of Experience: Mature Workers in the Future Workforce, 2002).

One of the many findings (ex. Edmunds, 2010) offers some interesting ideas, such as: a) retirement can represent a major loss to a person's sense of self, but prolonging working life can help provide purpose in life; $b$ ) a link exists between a person's perception of their age and their work ability - workers who feel young have higher self-reported work performance and ability; c) the mental health of older adults who continue to work improves as a result of increased social engagement. Anyway, researchers agree upon the fact that moving from the role of an employee to the role of the unemployed may be a complex and puzzling experience.

According to Nordenmark \& Strandh (1999), unemployment not only affects a person's economic resources, but it also affects a person's psychosocial well-being. Because work is typically an important part of a person's life, retirees face a multitude of work-related concerns such as job loss, grief, guilt, loss of self-esteem, loss of identity and loss of social support and contacts (Archer, Rhodes, 1993). In addition, they suffer increased depression, anxiety and physical illness when compared with people who were employed (Turner et al., 1991).

In spite of the fact that there are many benefits of prolonging working life, little research has addressed how older workers determine themselves ready to retire. However, the usual age to retire may vary across occupations. In addition, although there are universal similarities, there also exist cultural differences (among ethnic backgrounds) that are related to families and communities. How can employees make informed decisions on when or not to retire? Besides financial security, current studies have focused on health status as a decision-making influence. Similarly, the increasing cost of healthcare insurance coverage also plays an important role as older adults examine their retirement options. To maintain a quality lifestyle and age successfully, individuals must consider whether or not retirement will meet their needs. Otherwise, this cohort may make decisions that may not be beneficial for them, their families or employers (Spokus, 2010). The only way to discover older workers' needs and expectations at work is communication, which is based on mutual trust and commitment.

When striving to retain older workers, one of the basics is to know why employees stay with a company. They may stay for many reasons, such as: interesting work, appreciation of work, feeling "in on things", job security, good wages, promotion opportunities, good working conditions or personal loyalty. If we take this same list and put "lack of" in front of any of those reasons, this can also be the reason why employees leave (Rubin, 2007). Knowing what motivates and what discourages older workers from prolonging their working lives is one of the crucial tools that HR management can use to influence the workers' final decision.

\section{WHY WOULD EMPLOYERS TRY TO PERSUADE OLDER WORKERS TO PROLONG WORKING LIFE?}

Assuming higher longevity and lower birthrate will constantly cause population and workforce aging, it might happen that there will not be enough younger and skilled workers to replace those who get retired and we can 
expect skills and labor shortages. Thus, it seems more than reasonable to pay more attention on older workers, as they might represent an important source of additional labor.

Despite myths and stereotypes concerning older workers, firms who actually employ them say that they do make excellent employees. Many researches (ex. McIntosh, 2001) confirm that, in general, older workers: have low turnover rates, are flexible and open to change, possess up-to-date skills, are interested in learning new tasks, do not experience transportation problems, are willing to take on challenging tasks, have low absentee rates, and have few on-the-job accidents.

Moreover, a research (Lackey, 2008) shows, that employees age 63 and older have higher levels of engagement and enthusiasm at work than any other generation. Klein (in Selko, 2008) says that older employees are more informed about a company's strategies and are more passionate about the work they are doing because they enjoy it. The same survey (Lackey, 2008) showed that across all generations, there was an observable correlation between an employee's tenure and his or her enthusiasm for their job.

According to the results of Sirota's research (in Lackey, 2008), traditionalists $^{1}$ have the highest overall satisfaction with their employers, are tied with baby boomers as the most willing to 'go the extra mile' for their employers, have the most pride in working for their employers, feel strongest that they are fairly compensated for their work, have the highest satisfaction with the jobs they perform, and feel strongest that their jobs make good use of their skills and abilities.

Considering the fact, that traditionalists consistently showed higher engagement levels compared to the other three generations, are best able to understand how their job connects to the overall goals of the company, are the most satisfied with their jobs, and are among the most likely to advocate for the company (the same source), there should be no doubt that it is worthy to pay attention to older employees.

Of course, there is a dilemma of whether older workers are able to perform those jobs that require physical strength, endurance, and quick reflexes. The first truth about older workers is that they don't fit one unique profile, but they differ from one another (Fyock, 1993). However, studies have shown that age, of itself, "does not affect ability" (Carnevale and Stone, 1994). Thus, just like members of any other age group, older adults who keep their bodies in good physical condition are fully capable of maintaining positions that require physical strength, endurance, and quick reflexes (McIntosh, 2001).

Further on, even if it is absolutely true, that older workers make excellent employees, employers can still be skeptical about whether it is cost effective to employ them or not. Fortunately, countless examples demonstrate that it can be effective and many researchers demonstrated that the contributions of older workers outweighed their costs to the company (ex. Brooke, 2003). Although older employees draw higher wages, they also quit less often, which, in the long run, save the company money in recruiting and training costs. Furthermore, even though they tend to spend more time on the telephone with customers, they also have higher booking rates (Useem, 1998). Surveys, studies and anecdotes all confirm that hiring older workers is an intelligent solution to the impending worker drought (McIntosh, 2001).

However, it is far from easy to lure older workers out of retirement, and back into the workforce or to convince them to prolong their working life. Moreover, the process of changing mental models between employers can be even more long-lasting. In many countries employers still failed to see a reason to encourage older workers to stay on the job (Carnevale and Stone, 1994). The situation in Slovenia is even worse (Žnidaršič, 2008). It is therefore critical that we turn our attention to specific ways to reach this under-appreciated and under-utilized segment of the labor force.

\footnotetext{
${ }^{1}$ The study (Lackey, 2008) encompassed four generational groups: a) traditionalists, ages 63 and older; b) baby boomers, ages 43-62; c) generation $X$, ages 28-42, and d) generation $\mathrm{Y}$, ages 27 and younger.
} 


\section{HOW TO CONVINCE OLDER WORKERS TO STAY: A SIMPLE FORMULA}

As already said, especially in Slovenia, the trends toward ending one's working life early have been notably strengthened by early retirement models that arose through factors such as industry restructuring, technological advances, downsizing, and so on. In the past two decades, these models have made it possible for people in the majority of developed countries to enter retirement even before turning sixty.

However, with recent and future changes in age structure of the populations, there is growing uncertainty about economic security in retirement in developed countries round the world. We can already face the reverse trend on demand and supply sides. Older workers are increasingly working past the age of 65 and employers are getting more and more aware that their sustainable business success will depend a lot on loyal staff members who enjoy their jobs. Recently, it has become clear that long term survival of many companies will rely on older employees. Thus, HR managers round the world are facing a challenging question - how to recruit the best people (regardless of their age) and then how to retain them.

Considering the fact that older workers can always choose between "to stay" or "not to stay" at work, once you have 'got' them, does not mean you cannot lose them. The first and the most obvious key to retain older workers is to know what they want and need. The second is to provide it. Thus, it is of essential importance to go and talk to older employees and make sure they are getting what they need from your company.

There are basically three essential retention strategies (McIntosh, 2001): (1) becoming the kind of company for which older workers want to work; (2) reorganizing company benefits, programs, and job structure to meet the needs of an aging workforce; and (3) keeping all employees' skills current by means of training and retraining programs. Anyway, a basic tool to make older workers' secret dreams to come up on the surface is communication.

Communication makes it possible to discuss the older workers' special needs and to clarify the expectations. Through communication process management can adapt the benefits and awards to each individual worker. In short, everyone wants to be heard, be it in private life or at work. The "formula" seems to be simple: communication satisfaction influences job satisfaction and satisfied worker is loyal worker, eager to stay and to prolong the working life (Figure 1).

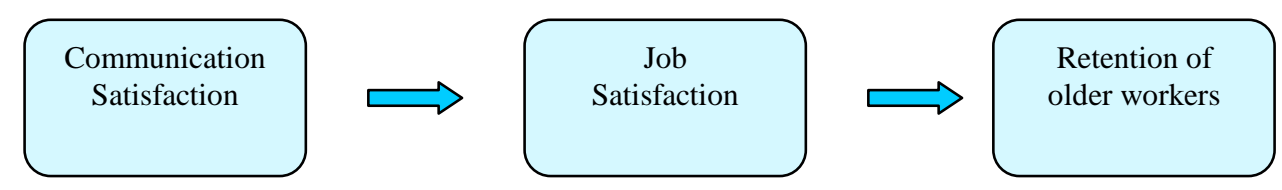

Figure 1: How To Convince Older Employees To Stay: A Simple Formula

It is well known, that the success of any organization depends on staff members who enjoy their jobs and feel rewarded by their efforts. In general, age may affect job satisfaction and work attitudes in several different ways. Early research in this area found a U shaped relationship between age and job satisfaction. Herzberg, et al. (1957) found that individuals' level of job satisfaction declined through their career then rose later in the individual's life.

While individuals do change jobs, older employees will tend to have longer tenure than younger employees. In their study of rural Southern blue collar employees, Gibson and Klein (1970) found that tenure was negatively associated and employee age was positively associated with overall job satisfaction. However, Near et al. (1978) found that job tenure was positively associated with job satisfaction.

A generalized view that job satisfaction increases with age leaves out a number of other variables that have an equal or greater effect on job satisfaction, especially individuals' perception of how the job meets their needs and expectations (Prien, Pitts, Kamery, 2004). This is why, it is of special importance to get to know the older 
employees' needs and expectations and this can be done through communication. Seeking information about employees can provide more answers to unknown perceptions and build on retention strategies.

Moreover, the survey (Rubin, Palmgreen, Sypher, 1994) proved the communication satisfaction to be a valid instrument correlating with job satisfaction, organizational commitment, and turnover rates. Thus, it is of crucial importance to audit ${ }^{2}$ the employee satisfaction with communication content, channels, feedback levels, types of communication (verbal and non-verbal), and frequency of communications.

Similarly, the research findings (Carrière, Bourque, Bonaccio, 2007) also confirm that communication satisfaction fully mediates the relationship between internal communication practices and the two work outcomes: job satisfaction and affective organizational commitment.

These finding are significant for several reasons. First, it has a fundamental practical implication for managers: internal communication systems that fail to generate communication satisfaction amongst (older) employees will not foster job satisfaction or affective organizational commitment. Second, the finding that communication satisfaction mediates the effects of communication practices on multiple job outcomes suggests the possibility that communication satisfaction may be a fundamental 'yardstick' against which employees appraise all of an organization's operating activities and change initiatives (the same source). Moreover, it can be logically assumed, that communication satisfaction might have strong impact on older workers' decision about getting retired or staying at work.

We can clearly see that it is of extreme importance for managers to build effective communication with their employees, including older workers. It is important to simultaneously measure the communication satisfaction, thus enabling to improve the weak points within established communication climate. Downs and Adriane (2004) suggest measuring eight specific dimensions of communication satisfaction: a) satisfaction with communication climate; b) satisfaction with communication with supervisors; c) satisfaction with organizational integration; d) satisfaction with media quality; e) satisfaction with horizontal and informal communication; f) satisfaction with organizational perspective; g) satisfaction with communication with subordinates; and h) satisfaction with personal feedback. The last one seems to be one of the strongest dimensions, especially concerning the questions of how workers are being judged and performance appraised.

\section{WHICH GROUP OF OLDER EMPLOYEES COMMUNICATION REALLY MATTERS TO?}

The recent research that has been done between older employees in Slovenia showed that it is worth to communicate with employees about decisions concerning retirement versus prolonging working life. A research has focused on questions concerning reasons for retirement, motives for extending their periods of employment and on general susceptibility to the employer measures that influence working life extension. Within the broad research, the factor analyses - conducted for twenty-four employer's measures for encouraging extension of the employment period - proved only one factor to be relevant (Figure 2). This proves that the employee responds to all of the measures or none at all.

\footnotetext{
2 A communication audit is defined as "merely a process of exploring, examining, monitoring, and evaluating something" (Downs \& Adrian, 2004). Audits focus primarily on communication, trying to understand the current state of the organization, and determining how employee messages establish interactions with each other (Downs \& Adrian, 2004).
} 


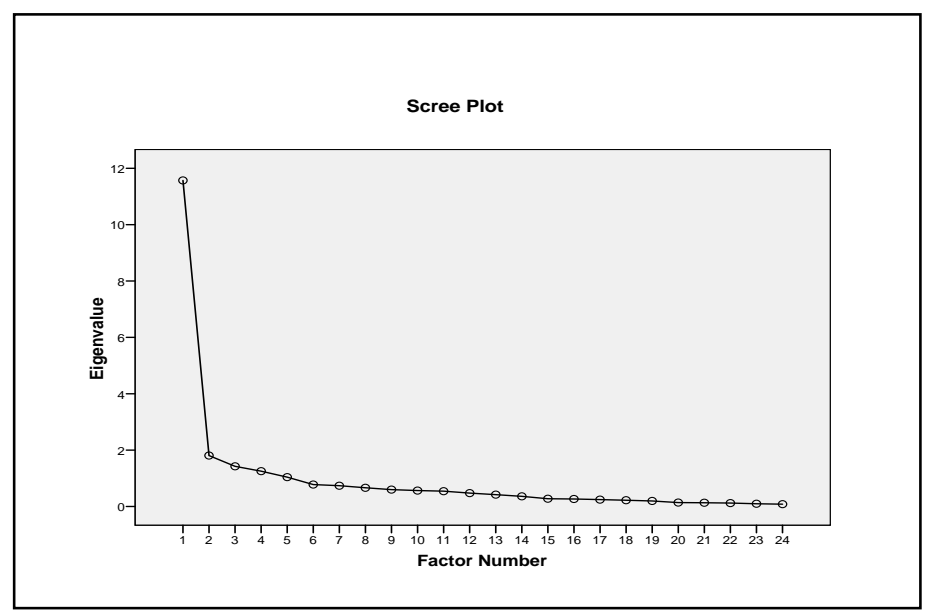

Figure 2: The Results Of Factor Analysis For Employer Measures For Encouraging Extension Of The Employment Period (The Constitution Of 1 Factor) Source: Author's Research.

It can be concluded from the above that older employees can be divided into two groups, which was verified using a statistical method of organizing units into groups, otherwise known as cluster analysis.

A T-test confirmed that the two employee groups differ (with a statistically significant difference) in nearly all of the characteristics studied: the inclination towards retirement in terms of two factors (the jump factor or external reasons, and the push factor or stress, strain, and uncertainty), the inclination towards extending their working lives, and the susceptibility to the employer measures. Only in the pull factors (the desire to enjoy one's free time) there were no statistically significant differences between the two groups (Table 1). The cluster analysis thus confirmed the results of the factor analysis: there are in fact two groups of older employees, which can be referred to as "susceptible" and "insusceptible" in terms of how the employer can affect their decisions.

However, both the statistical (factor) analysis and cluster analysis, which were conducted as part of the quantitative study and the analysis of qualitative interviews, showed that some older employees are extremely eager to retire. They cannot be influenced by any employer measure. As a result of the cluster analysis, they were called "the unsusceptible." These employees have already decided to retire as soon as possible. Employers should be interested primarily in those employees who are inclined towards extending their period of employment and represent labour potential. Those employees are worth paying attention on and they deserve good communication that would help to make their personal needs and the company goals compatible.

\section{THE ROLE OF COMMUNICATION IN STRIVING TO RETAIN OLDER EMPLOYEES}

The importance of communication in retaining older employees has been proven in many researches. When workers were asked what would make them happy at work, the answer varied depending on who was asked. Anyway, the top three aspects that were "very important" to worker satisfaction included (SHRM, 2004): a) job security $(65 \%)$; b) benefits $(64 \%)$; and c) communication between employees and management (62\%). HR professionals claimed on communication as the most important factor for satisfaction. Similarly, HR professionals ranked the following as "very important" to workers' happiness (SHRM, 2004): a) communication between employees and management (77\%); b) recognition by management $(62 \%)$; and c) relationship with immediate supervisor $(61 \%)$. 
Table 1: Cluster Analysis: The Two Employee Groups Testing

\begin{tabular}{|c|c|c|c|c|c|c|c|c|c|c|}
\hline \multicolumn{11}{|c|}{ Independent Samples Test } \\
\hline & & \multicolumn{2}{|c|}{$\begin{array}{l}\text { Levene's Test for } \\
\text { Equality of Variances }\end{array}$} & \multicolumn{7}{|c|}{ t-test for Equality of Means } \\
\hline & & \multirow[b]{2}{*}{$\mathrm{F}$} & \multirow[b]{2}{*}{ Sig. } & \multirow[b]{2}{*}{$t$} & \multirow[b]{2}{*}{ df } & \multirow[b]{2}{*}{ Sig. (2-tailed) } & \multirow{2}{*}{$\begin{array}{c}\text { Mean } \\
\text { Difference }\end{array}$} & \multirow{2}{*}{$\begin{array}{l}\text { Std. Error } \\
\text { Difference }\end{array}$} & \multicolumn{2}{|c|}{$\begin{array}{l}\text { 95\% Confidence } \\
\text { Interval of the } \\
\text { Difference }\end{array}$} \\
\hline & & & & & & & & & Lower & Upper \\
\hline \multirow[t]{2}{*}{$\begin{array}{l}\text { Inclination towards } \\
\text { retirement }\end{array}$} & $\begin{array}{l}\text { Equal variances } \\
\text { assumed }\end{array}$ & \multirow[t]{2}{*}{6,149} & \multirow[t]{2}{*}{, 016} & \multirow{2}{*}{$\begin{array}{l}-9,680 \\
-9,474\end{array}$} & \multirow{2}{*}{$\begin{array}{r}70 \\
56,634\end{array}$} & \multirow{2}{*}{$\begin{array}{l}, 000 \\
, 000\end{array}$} & \multirow{2}{*}{$\begin{array}{r}-1,468880 \\
-1,468880\end{array}$} & \multirow{2}{*}{$\begin{array}{l}, 15174046 \\
, 15503820\end{array}$} & \multirow{2}{*}{$\begin{array}{l}-1,77152 \\
-1,77938\end{array}$} & \multirow{2}{*}{$\begin{array}{l}-1,16624 \\
-1,15838\end{array}$} \\
\hline & $\begin{array}{l}\text { Equal variances } \\
\text { not assumed }\end{array}$ & & & & & & & & & \\
\hline \multirow[t]{2}{*}{ External reasons } & $\begin{array}{l}\text { Equal variances } \\
\text { assumed }\end{array}$ & \multirow[t]{2}{*}{6,042} & \multirow[t]{2}{*}{, 016} & $-9,569$ & 70 & \multirow{2}{*}{$\begin{array}{l}, 000 \\
, 000\end{array}$} & \multirow{2}{*}{$\begin{array}{l}-1,553675 \\
-1,553675\end{array}$} & \multirow{2}{*}{$\begin{array}{r}, 16236324 \\
, 16466683\end{array}$} & \multirow{2}{*}{$\begin{array}{l}-1,87750 \\
-1,88284\end{array}$} & \multirow{2}{*}{$\begin{array}{l}-1,22985 \\
-1,2245\end{array}$} \\
\hline & $\begin{array}{l}\text { Equal variances } \\
\text { not assumed }\end{array}$ & & & $-9,435$ & 62,006 & & & & & \\
\hline \multirow[t]{2}{*}{ Stress and strain } & $\begin{array}{l}\text { Equal variances } \\
\text { assumed }\end{array}$ & \multirow[t]{2}{*}{1,637} & \multirow[t]{2}{*}{,205 } & $-2,906$ & 70 & \multirow{2}{*}{$\begin{array}{l}, 005 \\
, 005\end{array}$} & \multirow{2}{*}{$\begin{array}{l}-, 63895657 \\
-, 63895657\end{array}$} & \multirow{2}{*}{$\begin{array}{l}, 21985913 \\
, 22026065\end{array}$} & \multirow{2}{*}{$\begin{array}{l}-1,07745 \\
-1,07842\end{array}$} &,- 200461 \\
\hline & $\begin{array}{l}\text { Equal variances } \\
\text { not assumed }\end{array}$ & & & $-2,901$ & 68,556 & & & & &,- 199498 \\
\hline $\begin{array}{l}\text { Desire to enjoy } \\
\text { one's free time }\end{array}$ & $\begin{array}{l}\text { Equal variances } \\
\text { assumed }\end{array}$ & ,482 & ,490 & ,831 & 70 & ,409 & , 19453074 & ,23404578 &,- 272259 &, 66132032 \\
\hline & $\begin{array}{l}\text { Equal variances } \\
\text { not assumed }\end{array}$ & & & ,822 & 63,737 & ,414 & & ,23674102 &,- 278451 & ,66751294 \\
\hline $\begin{array}{l}\text { Inclination towards } \\
\text { extending working }\end{array}$ & $\begin{array}{l}\text { Equal variances } \\
\text { assumed }\end{array}$ & 120 & ,730 & $-2,576$ & 66 & ,012 &,- 59669710 & ,23164180 & $-1,05918$ &,- 134209 \\
\hline & $\begin{array}{l}\text { Equal variances } \\
\text { not assumed }\end{array}$ & & & $-2,587$ & 65,845 &, 012 &,- 59669710 & & $-1,05725$ &,- 136144 \\
\hline $\begin{array}{l}\text { Susceptibility to } \\
\text { the employer }\end{array}$ & $\begin{array}{l}\text { Equal variances } \\
\text { assumed }\end{array}$ & ,003 & ,958 & $-3,836$ & 70 & ,000 &,- 84486463 & ,22025293 & $-1,28415$ &,- 405584 \\
\hline measures & $\begin{array}{l}\text { Equal variances } \\
\text { not assumed }\end{array}$ & & & $-3,861$ & 70,000 &, 000 &,- 84486463 & ,21883164 & $-1,28131$ &,- 408419 \\
\hline
\end{tabular}

Source: author's research, Žnidaršič 2008.

Organizations that have a culture of trust and inclusion solve age-management issues with open, healthy dialogue that begins with assessment of the current situation and present and future needs in human-resources management. This continues throughout the entire process of attraction, selection, hiring, orientation, career development, retention, and joint retirement planning. It is key that subordinates are listened to in order to discover their specific needs and recognize problems (Ford, 2005), and at the same time communication can serve to personalize activities to fit the individual.

Parkinson (2002) notes that communication between older workers and management is generally more personal, but it is also very often underrated, which leads to misunderstandings and disappointment. Older workers naturally expect that they will be offered development opportunities, that their efforts will be noticed, and that these efforts will be rewarded. Communication allows workers to alert management to more or less explicit impressions and experiences of age discrimination that management may not perceive, particularly in youth-oriented organizations. In order to retain older workers it is very important for them to feel valued and not to be exposed to stress (McIntosh, 2001). Being able to turn to the management at any time, and knowing exactly who they can turn to when problematic situations arise, is extremely important to employees (Yeandle, 2005). McIntosh (2001a) recommends frequent personal conversations with individual employees, which may be informal and take place during breaks, lunch, and so on. Steinhauser (1999) recommends introducing focus group interviews for older workers that also include people that have just retired from the organization. This type of interview allows problematic situations having to do with age to be identified. An example of this type of problem is if the organization equates success with youth. 
Communication is the most important tool available to human-resource managers for aligning individuals' goals with those of the organization ${ }^{3}$. Morton, Foster, and Sedlar (2005) advise continuously testing how open internal communication channels are, especially when introducing changes that include the employees (e.g., new age-management strategies, etc.). Communication is also a key in disseminating the organization's mission and vision, which includes age management as a component part, among all employees, thus encouraging a culture of intergenerational coexistence. It is also important to communicate with the local community because age management at an organization is only effective when there is sufficient support at the macro level.

Age management must include a high level of communication, especially with regard to the main problems older employees face. Communication is a key management tool in the process of harmonizing psychological contracts (Branham, 2005) and also in preparing older employees for retirement. Awareness-raising and joint financial planning related to retirement are good examples of improving retirement readiness: management must encourage employees to learn about their retirement possibilities and potential retirement reforms and to participate in this (Morton, Foster, Sedlar, 2005), which is ensured with a combination of online communication and opportunities for individual discussions. The same writers recommend forming and developing affinity groups that bring together older employees in the organization and work strategically as incubators for developing agemanagement ideas with contributions from both employees and employers. At the same time, these groups conduct research and seek solutions to problems connected with an aging workforce.

With increasing privatization of social security models, communication between all generations is also becoming important, such as in the context of retirement savings plans that encompass all employees, including young ones. Among older workers, the most pressing issue is to communicate with them about extending their working lives, and particularly about opportunities for flexible transitions into retirement. Enabling an employee's advancement in a timely fashion or entrusting employees with more responsible work could offer a new source of energy, stimulate interest in work, and thus offer a significant incentive for extending one's working life, especially if this is also in the organization's interest. Parkinson (2002) notes that it is practical to communicate about employees' retirement intentions well in advance of the time they intend to completely withdraw from working life. Kidrič (2007) emphasizes the importance of being informed in decision-making regarding extending one's working life or retiring. Employees should be notified of their retirement status at least ten years before reaching retirement age. They should receive a statement of their retirement base - their pay and calculations of their anticipated retirement benefits under various scenarios - and should have access to their employment savings account status, as is done in the case of the Swedish "orange envelope"4 (Parkinson, 2002).

Keeping the lines of communication open can be very efficient in striving to retain older workers. Personal communication and interaction with company leaders can go a long way to help foster organizational trust and a spirit of unity (Goldberg, 2000). Managers and executives should send memos, reports, and letters directly to employees instead of channeling them through formal corporate communications departments. For HR manager or direct superior, it is of vital importance to be available and accessible to his/her employees when feasible. Informal channels of communication are very successful, for example inviting employees to take a break with you - as a boss and get acquainted with them as individuals to show them your interest is genuine (Gransbury, 1995). While you don't want to favor or single out older workers, these employees, in particular, may appreciate your efforts to get to know them and to establish mutual respect.

However, the communication between management and older workers is not important only when considering prolonging one's working life, but it is of equal importance also when considering retirement (options). HR manager should keep in mind, that retiring is not just about reaching a certain age or working until an agreed date. A good manager would plan the retirement process of every mature worker in order to: a) manage the spread of

\footnotetext{
${ }^{3}$ One in three workers considers leaving his job if "they don't listen to him." American research reveals that the four top reasons for employee turnover are: that management does not listen to employees' problems, suggestions, etc.; low pay; poor internal communication and lack of perception; and inadequate rewards (Kranz, 2007).

${ }^{4}$ The essence of the Swedish "orange envelope" project is that notional defined contribution (NCD) retirement benefit systems record data on the contributions paid by each individual, revalue them on an ongoing basis, and form a "retirement credit." At the same time, Swedish workers receive an "orange envelope" each year: notification of their retirement benefit balance, which is further supplemented by projections under various scenarios.
} 
skills throughout the organization; b) develop mentoring or coaching roles for older workers so expertise is not lost, and c) ensure older workers have a soft landing into their life after work.

In the case of older workers the subject of discussion - be it through informal chats or more formal appraisal interviews - is often centered on retirement plans, because for every single older worker planning retirement is vital. HR management should make it clear how will: retirement affect the business - in terms of the mix of skills and opportunities for junior workers; expertise be kept within the business beyond retirement; the retirement process be built into career planning in the future, and employees be prepared for life after retirement. By talking these things through, management is less likely to be surprised by sudden shortages in staff or skills and when communication ideally flows, both - manager and an employee - have time to prepare for retirement.

Still, getting leaders to communicate both clearly and concisely can be a real challenge, especially if they are uncertain as to what exactly is expected of them and what "good" communication looks like in action. Getting to the end of this paper, we want to shed the light on some communication fields that need to be covered when striving to retain older employees (Table 2).

Table 2: The List Of Communication Fields - Covered Within Retention Strategy Implementation

\begin{tabular}{|c|c|c|}
\hline Communication field & \begin{tabular}{|c|} 
Communication subject \\
\end{tabular} & Benefits and Results of Communication \\
\hline $\begin{array}{l}\text { Changing mental models } \\
\text { (among employers and } \\
\text { employees) }\end{array}$ & $\begin{array}{l}\text { The consequences of population ageing, characteristics } \\
\text { of the culture of age-friendly organization, succession } \\
\text { management. }\end{array}$ & $\begin{array}{l}\text { Increasing awareness about what age-friendly } \\
\text { organization means. } \\
\text { The promotion and implementation of age } \\
\text { management strategies. }\end{array}$ \\
\hline Knowledge management & $\begin{array}{l}\text { Additional education and training needed, knowledge } \\
\text { transfer, knowledge recovery... }\end{array}$ & Keeping older workers' skills up-to date. \\
\hline $\begin{array}{l}\text { Health management and } \\
\text { work place management }\end{array}$ & $\begin{array}{l}\text { Health prevention, safety at work, work loads, healthy } \\
\text { work environment, restructuring of job positions, } \\
\text { alternative career paths, and flexible forms of } \\
\text { employment. }\end{array}$ & $\begin{array}{l}\text { Increased job satisfaction, dedication and } \\
\text { organizational commitment that lead to higher } \\
\text { inclination to stay at work. }\end{array}$ \\
\hline Reward system & $\begin{array}{l}\text { The right mix of rewards (the base pay, a variable part of } \\
\text { the salary, and benefits, as well as the psychological } \\
\text { perception of work - the psychological contract). }\end{array}$ & $\begin{array}{l}\text { When older employees feel that they are not well- } \\
\text { rewarded and the psychological contract between the } \\
\text { employer and employees is shaky, employees will } \\
\text { consider opportunities for early retirement. } \\
\text { Personalizing rewards to suit the individual! }\end{array}$ \\
\hline $\begin{array}{l}\text { Management of different } \\
\text { generations }\end{array}$ & $\begin{array}{l}\text { Discussing generational differences; conflicts that arise } \\
\text { from generation differences. }\end{array}$ & $\begin{array}{l}\text { The optimal age structure while avoiding generational } \\
\text { conflicts through quality communication. }\end{array}$ \\
\hline Retirement planes & $\begin{array}{l}\text { The financial security, the mix of skills and opportunities } \\
\text { for workers; expertise that should be kept within the } \\
\text { business beyond retirement; the retirement process that } \\
\text { should be built into career planning in the future, phased } \\
\text { retirement models and employee' preparedness for life } \\
\text { after retirement. }\end{array}$ & $\begin{array}{l}\text { Management is protected from sudden shortages in } \\
\text { staff or skills. } \\
\text { When communication ideally flows, both - manager } \\
\text { and an employee - have time to prepare for } \\
\text { retirement. }\end{array}$ \\
\hline Leadership & Leadership styles, trust, respect. & $\begin{array}{l}\text { Improving relations between management and } \\
\text { employees. }\end{array}$ \\
\hline $\begin{array}{l}\text { Key barriers to employee } \\
\text { retention }\end{array}$ & $\begin{array}{l}\text { Age discrimination, problems with approval for on-the- } \\
\text { job education and training, inability to ensure work-life } \\
\text { balance, and health problems. }\end{array}$ & $\begin{array}{l}\text { Combating age barriers and enabling age-friendly } \\
\text { working environment. }\end{array}$ \\
\hline $\begin{array}{l}\text { Communication } \\
\text { satisfaction as such }\end{array}$ & $\begin{array}{l}\text { Satisfaction with communication climate; satisfaction } \\
\text { with communication with supervisors; satisfaction with } \\
\text { organizational integration; satisfaction with media } \\
\text { quality; satisfaction with horizontal and informal } \\
\text { communication; satisfaction with organizational } \\
\text { perspective; satisfaction with communication with } \\
\text { subordinates; and satisfaction with personal feedback. }\end{array}$ & $\begin{array}{l}\text { The formation of affinity groups of older employees. } \\
\text { Good relations between all employees. } \\
\text { Communication satisfaction improves job satisfaction } \\
\text { and commitment which lead to loyalty and higher } \\
\text { inclination towards prolonging working life. }\end{array}$ \\
\hline
\end{tabular}




\section{CONCLUSION}

Since the end of the second world war there has been a trend towards early retirement (before age 65), although this has started to slow and older workers are increasingly working past the age of 65 . This is mostly due to growing uncertainty about economic security in retirement in developed countries round the world. Considering the current demographic trends, older workers will definitely represent the important percent of labor pool and in the most developed countries older workers are already very appreciated as additional labor force.

However, in many countries employers still failed to see a reason to encourage these workers to stay on the job (Carnevale and Stone, 1994). The situation in Slovenia is even worse (Žnidaršič, 2008). It is therefore critical that we turn our attention to specific ways to reach this under-appreciated and under-utilized segment of the labor force.

There are basically three essential retention strategies we mentioned in the paper: (1) becoming agefriendly employer - a company for which older workers want to work; (2) reorganizing working processes to meet the needs of an aging workforce; and (3) keeping all employees' skills up-to-date.

Among the company policies that are aimed to retain older employees and are refereed as age management, the communication can play a special role. We can generalize, that good management is about good communication, no matter what the age of the employee. Communication makes it possible to discuss the older workers' special needs and to clarify the expectations. Through communication process management can adapt the benefits and awards to each individual worker. In short, the (older workers') retention "formula" seems to be simple: communication satisfaction influences job satisfaction and satisfied worker is loyal worker, eager to stay and to prolong the working life. Actually, communication is a tool that brings the individual and company needs on the same side of the river, enabling mutually beneficial combinations. Thus, the paper was focused primarily on the role of communication in fostering to persuade older employees to stay active.

Besides, we shed light on the role of communication in age management, we also suggest some ideas how to improve the communication with older employees. Finally, the main communication fields - that have to be covered when HR management and top management want to provide the working environment that would foster older workers to prolong their working lives - are addressed.

However, one should keep in mind, that recommendations considering communication as part of the overall active aging strategy that were presented in the paper are just a starting point for companies wishing to retain older workers. When becoming an age-friendly organization, every company must begin with changes in attitudes toward mature employees, with the special emphasize on combating against negative stereotypes. If such changes are not followed by the reorganization of working environment, benefits packages, job structure, and company policy, older workers will not be adequately motivated to stay. To achieve the best results within retention strategy, communication is of essential importance, be it formal or informal, starting with changing the assumptions about older adults, who deserve to be treated as valuable employees and as individuals.

\section{AUTHOR INFORMATION}

Sandra Penger, Ph.D., is assistant professor the Department of Management and Organization at the Faculty of Economics, University of Ljubljana (http://www.ef.uni-lj.si/en/). Her research interests are in economics of education, learning styles, authentic leadership, positive organizational behavior, learning organization and new public management. She attended many international conferences, where she presented papers in her research areas and published several articles in Slovene, European, and US journals. More information at http://www.ef.unilj.si/pedagogi/pedagog.asp?id=301, or via e-mail: sandra.penger@ef.uni-lj.si.

Jana Žnidaršǐ̌, Ph.D., is assistant professor the Department of Management and Organization at the Faculty of Economics, University of Ljubljana (http://www.ef.uni-lj.si/en/). Her research interests are in age management, business communication, economics of education, management process, organizational behavior, learning organization and new public management. She attended many international conferences, where she presented papers 
in her research areas and published several articles in Slovene, European, and US journals. More information at http://www.ef.uni-lj.si/pedagogi/pedagog.asp?id=356; or via e-mail: jana.znidarsic @ef.uni-lj.si.

Vlado Dimovski, Ph.D., is full professor at the Department of Management and Organization at the Faculty of Economics, University of Ljubljana (http://www.ef.uni-lj.si/en/). His research interests are in organizational learning, organizational social networks, authentic leadership, age management, and learning organization. His studies on knowledge management and organizational learning culture, using structural model and meta-analysis techniques for performance improvement relating to the Slovenian and Eastern Europe data assessment, are published in SCIE journals in the field of management, information technology, industrial and organizational behavior. More information at http://www.ef.uni-lj.si/pedagogi/pedagog.asp?id=65; or via e-mail: vlado.dimovski@ef.uni-lj.si.

\section{REFERENCES}

1. Archer, J. \& Rhodes, V. (1993). The grief process and job loss: A cross-sectional study. British Journal of Psychology, 84, 395-410.

2. Branham, L. (2005). The 7 Hidden Reasons Employees Leave. New York: American Management Association (AMACOM).

3. Brooke, L. (2003). Human resource costs and benefits of maintaining a mature-age workforce. International Journal of Manpower, 24(3), 260-283.

4. Carnevale, A. P. \& Stone, S. C. (1994). Developing the new competitive workforce. In Auerbach J. A., Welsh J. C. (eds.): Aging and competition: Rebuilding the U.S. workforce, (pp. 94-144). Washington D. C.: The National Council on the Aging \& the National Planning Association.

5. Carrière, J., Bourque, C. \& Bonaccio, S. (2007). The role of communication satisfaction as a mediator between an organization's internal communication systems and two job outcomes: job satisfaction and organizational commitment. Ottawa, Ontario: ASAC.

6. Downs, C. W., \& Adrian, A. D. (2004). Assessing organizational communication: Strategic communication audits. New York: The Guilford Press.

7. Edmunds, M. W. (2010). Bringing Retired RNs Back to Work. http://www.medscape.com/viewarticle/714797 (accessed 3. May 2010).

8. Ford, G. (2005). Am I Still Needed? Guidance and Learning for Older Adults. Derby: Centre for Guidance Studies, University of Derby.

9. Fyock, C. D. (1993). Get the Best: How to Recruit the People You Want. Homewood, IL: Business One Irwin.

10. Gibson, J. L. \& S. M. Klein (1970). Employee attitudes as a function of age and length of service: A reconceptualization. Academy of Management Journal, 13, 411- 425.

11. Goldberg, B. (2000). Age Works. New York, NY: The Free Press.

12. Gransbury, P. (1995). Motivation of the older worker. Supervision, (February).

13. Herzberg, F., Mausner, B., Peterson, R. O. \& Capwell, D. F. (1957). Job attitude research and opinions. Pittsburgh, Pennsylvania: Psychological Service of Pittsburgh.

14. Kidrič, D. (2007). Posameznik v socialnem zavarovanju (denarne in nedenarne pravice ter obveznosti). Odnos Slovencev do starosti, pokojninskega sistema in varčevanja za starost - Zbornik ob 10. obletnici Kapitalske družbe (pp. 48-50). Ljubljana: Kapitalska družba. In Slovenian.

15. Lackey, S. (2008). Older Workers Are Enthusiastic but Might Be Overlooked. HR Magazine (April).

16. McIntosh, B. (2001). An Employer's Guide to Older Workers: How to Win Them Back and Convince Them to Stay. Washington D.C.: U.S. Department of Labor, Employment and Training Administration, Area: Human Resource Management.

17. McIntosh, B. (2001a). Supervisor's Guide: Managing Aging Workers. Washington D.C.: U.S. Department of Labor, Employment and Training Administration, Area: Human Resource Management.

18. Morton, L., Foster, L. \& Sedlar, J. (2005). Managing the Mature Workforce, Implications and Best Practices. New York: The Conference Board.

19. Near, J. P., R.W. Rice \& R. G. Hunt (1978). Work and extra work correlates of life and job satisfaction. Academy of Management Journal, 21, 248 - 264. 
20. Nordenmark, M. \& Strandh, M. (1999). Towards a sociological understanding of mental well-being among the unemployed: The role of economic and psychosocial factors. Sociology, 33, 577-597.

21. Parkinson, D. (2002). Voices of Experience: Mature Workers in the Future Workforce. New York: The Conference Board.

22. Parkinson, D. (2002). Voices of Experience: Mature Workers in the Future Workforce. New York: The Conference Board.

23. Prien K. O., Pitts S. T., Kamery R. H. (2004). Job satisfaction in older workers: the case of a garment manufacturing company in Northwest Arkansas. Journal of Organizational Culture, Communications and Conflict, Jan.

24. Roper, ASW (2002). Staying Ahead of the Curve: The AARP Work and Career Study, A National Survey. Washington, DC: AARP.

25. Rubin, K. (2007). Motivation by Generation: From Matures and Baby Boomers to Gen Xer's and Beyond!. A summary of the session at IACC's 36th Annual Convention.

26. Rubin, R. B., Palmgreen, P., \& Sypher, H. E. (1994). Communication research measures. NewYork: Guilford Press.

27. Selko, A. (2008). Companies Need To Hire Older Workers. Industry Week, June 20. http://www.industryweek.com/articles/companies_need to hire_older_workers_16630.aspx (accessed 12. April 2010).

28. SHRM, the Society for Human Resource Management. (2004). What Makes Employees Happy? Press release, November 2004. http://www.insightlink.com/What_makes_employees_happy.html (accessed 12. April 2010).

29. Spokus, D. M. (2010). Retiring can be Hazardous to Mental and Physical Well-Being: Knowing When and How to Retire. http://www.personal.psu.edu/dms201/Retire.html (accessed 3. May 2010).

30. Steinhauser, S. (1999). Successfully Managing an Age Diverse Workforce. Managing Diversity, 8 (4). http://clem.mscd.edu/ steinhas/managing_diversity.htm (accessed 2. June 2008).

31. Turner, J., Kessler, R, \& House, J. (1991). Factors facilitating adjustment to employment: Implications for intervention. American Journal of Community Psychology, 19, 521-542.

32. Useem, M. (1998). Business restructuring and the aging workforce. In Auerbach J. A. (ed.), Through a Glass Darkly: Building the New Workplace for the 21 st Century. NPA Report \#289. Washington D.C.: National Policy Association.

33. Yeandle, S. (2005). Older workers and work-life balance. York: The Joseph Rowntree Foundation.

34. Žnidaršič, J. (2008). Age management: The Organizational model of active ageing. Doctoral dissertation. University of Ljubljana: faculty of economics. In Slovenian. 